\title{
A note on the seasonality of stock returns on the Johannesburg Stock Exchange
}

\author{
D.J. Bradfield \\ Department of Mathematical Statistics, University of Cape Town, Rondebosch, 7700 Republic of South Africa
}

\begin{abstract}
Evidence from studies on the major stock exchanges world-wide suggests that stocks listed on these markets earn abnormally high returns in the month of January. In this article the seasonality of stocks on the Johannesburg Stock Exchange is empirically investigated. Surprisingly no January effects are found, however, a significant December seasonal effect is documented. A plausible explanation for this finding is offered.

Getuienis uit studies op effektebeurse dwarsoor die wêreld dui aan dat aandele abnormale verdienstes gedurende Januarie verdien. In hierdie artikel word die moontlikheid van 'n soortgelyke verskynsel op die Johannesburgse Effekte Beurs empiries ondersoek. Verbasend word geen Januarie-effek gevind nie, maar wel 'n betekenisvolle Desember-effek. Moontlike verduidelikings vir hierdie bevinding word voorgestel.
\end{abstract}

\section{Introduction}

Practitioners world-wide have recognized the important role played by Capital Market Theory in the field of modern finance. Decision makers in this field have undoubtedly followed the empirical findings relating to Capital Market Theory with keen interest. The vast quantity of recent literature dealing with misspecifications of the Capital Asset Pricing Model (CAPM) is evidence of the demand by practitioners for research in this area. Of the recent findings, one in particular has captured the interest of the international investment community, namely, the overwhelming evidence of a January seasonal effect manifested in the estimate of the CAPM-based risk premium. This phenomenon has come to be known as the January effect and has been documented on most of the major stock markets world-wide. In this article the seasonality of stocks on the Johannesburg Stock Exchange (JSE) is investigated and compared to the existing international evidence.

Rozeff \& Kinney (1976), Keim (1983), and Roll (1983) were among the first researchers to identify that the New York Stock Exchange (NYSE) stock market returns are, on average, higher in January than any other month of the year. Attention subsequently shifted to investigating this effect on other stock exchanges as well. A summary of results from international stock markets was presented by Corhay, Hawawini \& Michel (1987). In particular they examined data from the New York (NYSE), the London (LSE), the Paris (PSE), and the Brussels (BSE) stock exchanges. They found seasonality in return existed in all of these exchanges in January. In addition, significant seasonality was found in other months as well. For example the LSE exhibited additional seasonality in April, the PSE in July, and the BSE in February, April, June, July and October.

Attempts to explain this January effect have been, at most, partially successful. The most popular hypothesis attributes the effect to year-end tax-loss selling. This hypothesis assumes that shares whose prices decreased during the year would be subject to selling pressure towards the end of the year. Consequently, prices are depressed prior to the end of the year and rebound at the beginning of January. Keim (1986) reviewed evidence in the literature which attempts to explain the January effect and suggested that liquidity or payroll effects may influence monthly returns.

\section{Testing methodology}

Some reseachers concerned with investigating seasonality in stock returns have considered this concept in conjunction with the size effect. However, Bradfield $(1988,1989)$ found no evidence of a size effect on the JSE (using both univariate and multivariate testing procedures). Hence, in this investigation the hypothesis of seasonality in JSE stock returns will be investigated separately.

The testing procedure outlined below aims at investigating whether seasonality exists in equally weighted indices constructed for this purpose. The rationale behind this approach is that returns of stock market indices (minus the risk-free rate) are usually used as surrogates for the excess market return (i.e. the risk premium) in the CAPM. Owing to the unique nature of the JSE, several indices were considered, namely an equally weighted mining share index, an industrial share index, and an all-share index. These indices were constructed from the record of trading statistics over the period January 1974-December 1984. All shares that had reliable records over this period were included in the respective indices. This amounted to 112 mining shares, 357 industrial shares, and 469 shares in total in the respective indices.

Weekly returns for each of the above-mentioned indices were computed, and subsequently partitioned and averaged within each of the relevant months of the year. This amounted to 11 data points (i.e. 11 years) associated with each of the 12 months for each of the three indices. This procedure is similar to the procedure outlined by Corhay, Hawawini \& Michel (1987).

\section{The JSE as a whole}

The results ${ }^{1}$ of the equally weighted all-share index constructed from the $469 \mathrm{JSE}$ stocks are shown in Table 1. Results from various other stock exchanges conducted over the 1970-1983 period (quoted in Corhay, Hawawini \& Michel, 1987) are also included in Table 1 for comparative purposes. 
Table 1 Seasonal results

\begin{tabular}{lccccc}
\hline Number of listed & NYSE & LSE & PSE & BSE & JSE \\
firms & 1490 & 2170 & 504 & 197 & 671 \\
Sample size & 782 & 527 & 112 & 170 & 469 \\
\hline January & $5,08^{\mathrm{a}}$ & $5,49^{\mathrm{a}}$ & $4,10^{\mathrm{a}}$ & $3,99^{\mathrm{a}}$ & 2,45 \\
& $(2,10)$ & $(2,04)$ & $(2,40)$ & $(4,08)$ & $(1,09)$ \\
February & 0,78 & 2,21 & 0,41 & $1,86^{\mathrm{a}}$ & 2,12 \\
& $(0,74)$ & $(1,58)$ & $(0,36)$ & $(2,72)$ & $(1,52)$ \\
March & 1,51 & 0,73 & 1,59 & 0,37 & 0,41 \\
& $(0,94)$ & $(0,42)$ & $(0,75)$ & $(0,49)$ & $(0,22)$ \\
April & 0,57 & $4,19^{\mathrm{a}}$ & 1,17 & $1,93^{\mathrm{a}}$ & 0,78 \\
& $(0,36)$ & $(3,31)$ & $(1,19)$ & $(2,71)$ & $(0,76)$ \\
May & $-0,70$ & $-0,48$ & $-0,69$ & $-0,08$ & 2,19 \\
& $(-0,50)$ & $(-0,41)$ & $(-0,45)$ & $(-0,13)$ & $(1,41)$ \\
June & 0,70 & $-1,39$ & $-1,56$ & $1,06^{\mathrm{a}}$ & 0,68 \\
& $(0,59)$ & $(-0,96)$ & $(-1,11)$ & $(2,06)$ & $(0,32)$ \\
July & 0,92 & 1,22 & $3,92^{\mathrm{a}}$ & $1,76^{\mathrm{a}}$ & $2,89^{\circ}$ \\
& $(0,67)$ & $(1,18)$ & $(2,76)$ & $(2,98)$ & $(2,02)$ \\
August & 1,06 & 1,13 & 1,96 & 0,28 & 2,57 \\
& $(0,66)$ & $(0,83)$ & $(1,52)$ & $(0,36)$ & $(1,21)$ \\
September & 0,31 & $-1,04$ & $-0,40$ & $-0,94$ & 1,39 \\
& $(0,23)$ & $(-0,52)$ & $(-0,21)$ & $(-1,17)$ & $(0,67)$ \\
October & $-0,91$ & $-0,07$ & $-1,76$ & $-1,48^{\mathrm{a}}$ & 1,25 \\
& $(-0,42)$ & $(-0,06)$ & $(-1,24)$ & $(-2,48)$ & $(1,34)$ \\
November & 2,25 & $-0,06$ & $-0,27$ & $-0,70$ & $-0,36$ \\
& $(1,22)$ & $(-0,03)$ & $(-0,22)$ & $(-0,98)$ & $(-0,26)$ \\
December & 1,48 & 1,62 & 0,37 & $1,58^{\mathrm{a}}$ & $2,78^{\mathrm{a}}$ \\
& $(1,31)$ & $(1,06)$ & $(0,41)$ & $(1,58)$ & $(2,96)$ \\
\hline & & & & & \\
& & & & &
\end{tabular}

$t$ statistics are in parenthesis. They are computed as $t(\bar{R})=$

$R^{-} \sqrt{n} / \sqrt{\sigma}(R)$ where $n=$ number of years

a significant at the $5 \%$ level for a one-sided alternative.

The result for JSE stocks in Table 1 is indeed surprising. It shows that an insignificant January effect exists for JSE stocks in the face of overwhelming evidence of a January effect in international markets. A significant July and December seasonal effect is, however, evident for JSE stocks.

Several hypothesis bave been offered for the January effect on the NYSE, and it is thus also conceivable that the significant January seasonals in the other international stock markets could be explained by similar hypotheses. Furthermore, the July seasonal on the PSE is likely to be caused by dividend payments (according to Hamon, 1986). Approximately two-thirds of all dividend payments in France are paid in July. The high incidence of significant monthly seasonals on the BSE, is however, difficult to explain. A plausible cause of this may be related to the relative size of the stock markets. Relative to the world market capitalization ${ }^{2}$ the BSE comprises $0,32 \%$ in contrast to 40,6 , and $1 \%$ for the NYSE, LSE, and PSE, respectively. Furthermore, substantially fewer shares are quoted on the BSE, namely 197 compared to 1490,2171 , and 504 on the NYSE, LSE, and PSE, respectively. Issues like thin and lacklustre trading on smaller markets may therefore have an influence on the variability of the outcome of tests on these markets. Explanations for the seasonal effects on the JSE shown in Table 1 will be offered in the final section of this article.

\section{The mining and industrial sectors on the JSE}

The results for the equally weighted mining and industrial indices are shown in Table 2. Results for the all-share index are included for comparative purposes.

From Table 2 it can be seen that the December seasonal effect is significant for all three data sets, and that the seasonal effect for July is significant at the $2,5 \%$ level for the mining index, whereas that for October is significant at the $5 \%$ level for the industrial index. Strictly speaking the test should have a two-sided alternative hypothesis to incorporate significantly poor months in the alternative hypothesis. This change would mean that the above significance levels are effectively doubled $^{4}$. Thus, the only other significant month at the $5 \%$ level besides December, occurs for mining stocks during July.

\section{Explanations}

Since dividends were not included in this study, the statistical significance is unlikely to be caused by dividends. Furthermore, dividend announcements are usually made in February or March for mid-year dividends and August or September for end-of-the-year dividends. Hence, the seasonal effect is unlikely to be caused by issues relating to announcements. It is possible that the July effect evident for mining stocks is a consequence of the particular sample period. However, the significant December effect occuring in all three indices is unlikely to be explained away as easily.

It is well known that thin and lacklustre trading on the JSE is characteristic of December, which is traditionally the holiday season in South Africa, and that this impacts on the volatility of stocks over this month. In particular, thin trading gives rise to non-synchronous prices being recorded, causing the variance of these returns to be underestimated over these periods. For example, if a particular share has not been traded for several weeks, its price will be recorded daily at the last transaction price, whereas the 'true' price varies according to the economic influences. Hence, the 'recorded' return series will have substantially less variability than the 'true' series. Although this argument can easily explain why the variance of daily or weekly returns in December, relative to other months, is underestimated, it does not fully explain why the series of monthly returns for each December over the sampled period exhibit relatively less volatility. However, the fact that large-scale selling or buying pressure over the December holiday period is unlikely may imply less variability in monthly December returns. From Table 2 it is seen that for the industrial index, December month had the smallest standard deviation. For the all-share index the second smallest standard deviation occurred in December, and for the mining index the December standard deviation was smaller than most other months, although not the smallest. In conclusion, it could be argued that the 
Table 2 Monthly returns for all-share, mining, and industrial indices

\begin{tabular}{|c|c|c|c|c|c|c|c|c|c|}
\hline \multirow[b]{3}{*}{ Months } & \multicolumn{9}{|c|}{ Equally weighted indices } \\
\hline & \multicolumn{3}{|c|}{ All-share } & \multicolumn{3}{|c|}{ Mining } & \multicolumn{3}{|c|}{ Industrial } \\
\hline & $\bar{R} \%$ & $t(\bar{R})$ & $\sigma(R) \%$ & $\bar{R} \%$ & $t(\bar{R})$ & $\sigma(R) \%$ & $\bar{R} \%$ & $t(\bar{R})$ & $\sigma(\mathbf{R}) \%$ \\
\hline January & 2,45 & 1,09 & 7,45 & 1,36 & 0,38 & 12,00 & 2,83 & 1,44 & 6,54 \\
\hline February & 2,12 & 1,52 & 4,64 & 2,34 & 0,88 & 8,84 & 2,10 & 1,67 & 4,16 \\
\hline March & 0,41 & 0,22 & 6,22 & 0.65 & 0,24 & 9,26 & 0,39 & 0,23 & 5,72 \\
\hline April & 0,78 & 0,76 & 3,43 & 0,52 & 0,28 & 6,09 & 0,87 & 0,90 & 3,20 \\
\hline May & 2,19 & 1,41 & 5,13 & 1,86 & 0,91 & 6,74 & 2,28 & 1,55 & 4,90 \\
\hline June & 0,68 & 0,32 & 7,03 & 0.70 & 0.22 & 10,40 & 0,71 & 0.38 & 6,23 \\
\hline July & 2,89 & a 2,02 & 4,74 & 5,99 & $b_{2,84}$ & 7,00 & 1,88 & 1,22 & 5,11 \\
\hline August & 2,57 & 1,21 & 6,88 & 2,59 & 0,66 & 13,02 & 2,47 & 1,43 & 5,72 \\
\hline September & 1,39 & 0,67 & 6,85 & 3,99 & 0,99 & 13,38 & 0,52 & 0,31 & 5,64 \\
\hline October & 1,25 & 1,34 & 3,10 & $-0,70$ & $-0,35$ & 6,62 & 1,77 & ${ }^{a} 1,87$ & 3,15 \\
\hline November & $-0,36$ & $-0,26$ & 4.66 & $-1,15$ & $-0,56$ & 6,84 & $-0,23$ & -0.16 & 4.80 \\
\hline December & 2,78 & 2,96 & 3,11 & 4,56 & $b_{2,28}$ & 7,23 & 2,01 & $b_{2,42}$ & 2,77 \\
\hline
\end{tabular}

"significant at the $5 \%$ level for a one-sided alternative

b significant at the $2,5 \%$ level for a one-sided alternative

significant seasonal effect in December is more likely to be a result of relatively less volatility than substantial return in December.

\section{Notes}

1. The average weekly returns in each month were converted to monthly returns for ease of comparison with the international evidence.

2. Source: Corhay, Hawawini \& Michel (1987).

3. Barr \& Bradfield (1988) offer a detailed explanation for why the variance of thinly traded stocks are usually underestimated.

4. The one-sided alternative $t$ values are used to be consistent with the Corhay et al. evidence.

\section{References}

Barr, G.D.I. \& Bradfield, D.J. (1988). Portfolio selection in thinly traded environments - a case study. Manage. Decision Econ., vol. 9, 287-290.

Bradfield, D.J., Affleck-Graves, J.F. \& Barr, G.D.I. (1988). Asset pricing in small markets - The South African case. S. Afr. J. Bus. Mgmt., vol. 19, 11-21.
Bradfield, D.J. (1989). Applications and extensions of financial models to small markets: The South African case. Unpublished Ph.D. thesis, University of Cape Town.

Corhay, A., Hawawini, G. \& Michel, P. (1987). Seasonality in the risk-return relationship. Some empirical evidence. J. Fin., vol. 42, 49-68.

Hamon, J. (1986). The reasonal character of monthly returns on the Paris Bourse (in French). Finance, vol. 7, 57-74.

Keim, D.B. (1983). Size-related anomalies and stock return seasonality: Further empirical evidence. J. Fin. Econ., 12, 13-32.

Keim, D.B. (1986). The CAPM and equity return regularities. Fin. Anal. J., vol. 42, 19-34.

Roll, R. (1983). Was ist das? The turn of the year effect and the premium of small firms. J. Portfolio Manage., vol. 9, 18-28.

Rozeff, M. \& Kinney, W. (1976). Capital market seasonality: The case of stock returns. J. Fin. Econ., vol. 3, 379-402. 